\title{
Field comparison of nitrous oxide emission measurements using micrometeorological and chamber methods
}

\author{
P Laville ${ }^{*}$, C Hénault ${ }^{2}$, P Renault ${ }^{3}$, P Cellier ${ }^{1}$, A Oriol $^{3}$, X Devis², D Flura ${ }^{1}$, JC \\ Germon $^{2}$ \\ I Unité de recherches en bioclimatologie, Inra, 78850 Thiverval-Grignon, France \\ 2 Centre de microbiologie du sol et de l'environnement, Inra, 17, rue de Sully, 21034 Dijon cedex, France \\ 3 Unité de science du sol, Inra, domaine Saint-Paul, site Agroparc, 84914 Avignon cedex 9, France
}

(Received 5 May 1997; accepted 15 December 1997)

\begin{abstract}
Summary - In order to check the reliability of micrometeorological and chamber methods for the measurement of $\mathrm{N}_{2} \mathrm{O}$ fluxes at the 'soil-atmosphere' interface, an experiment using these two methodologies was performed in autumn on a bare soil fertilized with $150 \mathrm{~kg} \mathrm{~N}-\mathrm{NH}_{4} \mathrm{NO}_{3} \mathrm{ha}^{-1}$. Micrometeorological measurements were continuously taken using either the gradient or eddy correlation methods, the $\mathrm{N}_{2} \mathrm{O}$ gas mixing ratio being measured with a tunable diode laser absorption spectrometer. $\mathrm{N}_{2} \mathrm{O}$ emission fluxes were also monitored in two automatic chambers during two 3-h periods every day, ie, around midday and midnight, whereas 16 manual chambers were monitored only around midday. Areas over which the fluxes were measured ranged from 0.18 and $0.49 \mathrm{~m}^{2}$ for the manual and automatic chambers, respectively, to more than $10^{4} \mathrm{~m}^{2}$ for the micrometeorological methods. Additional soil variables were obtained, including the soil bulk density profile, water content, temperature and $\mathrm{N}-\mathrm{NO}_{3}{ }^{-}$and $\mathrm{N}-\mathrm{NH}_{4}{ }^{+}$concentrations. The different methods provided similar estimates of $\mathrm{N}_{2} \mathrm{O}$ fluxes with an average over the whole of the common measurement period of around $6 \mathrm{ng} \mathrm{N}-\mathrm{N}_{2} \mathrm{O} \mathrm{m}^{-2} \mathrm{~s}^{-1}$. The 16 manual chambers showed coefficients of variation comprised between 30 and $150 \%$ during the 2 weeks of common observations. This variability may explain the unusual shape of the $\mathrm{N}_{2} \mathrm{O}$ concentration gradient in the atmosphere observed sometimes, which led to the conclusion that the gradient data set contained information allowing the spatial variability in $\mathrm{N}_{2} \mathrm{O}$ emission to be characterized. Hourly micrometeorological fluxes indicated a temporal variability of about $100 \%$ over daily periods. Microbial processes may be assumed to vary little over such a period and this temporal variability is probably a consequence of physical processes, such as air pressure fluctuations. Slight daily cycle tendencies were observed. The weak levels of $\mathrm{N}_{2} \mathrm{O}$ emissions were caused by rainfall deficit, which maintained the soil at a low water content, preventing strongly anaerobic conditions and the $\mathrm{N}$ fertilizer from leaching from the dry surface to wet soil layers. (@) Inra/Elsevier)
\end{abstract}

nitrous oxide flux / greenhouse effect / denitrification / soil / micrometeorological methods / chamber methods

Résumé - Comparaison au champ des émissions de protoxyde d'azote mesurées par méthodes micrométéorologiques et par méthodes des chambres. Afin de tester la fiabilité des méthodes micrométéorologiques et des méthodes par chambres au sol pour la mesure des flux de $\mathrm{N}_{2} \mathrm{O}$ à l'interface « sol-atmosphère », une expérimentation utilisant ces deux méthodologies a été conduite à l'automne sur un sol nu fertilisé préalablement par $150 \mathrm{~kg} \mathrm{~N}-\mathrm{NH}_{4} \mathrm{NO}_{3} \mathrm{ha}^{-1}$. Les mesures micrométéorologiques ont permis un suivi continu des émissions par la méthode des gradients ou par la méthode des corrélations turbulentes, les rapports de mélange en $\mathrm{N}_{2} \mathrm{O}$ étant mesurés par un spectromètre d'absorption

Article communicated by Steve Jarvis (North Wyke Okehampton)

* Correspondence and reprints

Tel: (33) 01308155 30; fax: (33) 01308155 63; e-mail: laville@bcgn.grignon.inra.fr 
à diode laser accordable. Ces mêmes émissions ont été aussi observées par deux chambres au sol à fonctionnement automatisé pendant deux périodes journalières de $3 \mathrm{~h}$ en milieu de journée et de nuit, et par seize enceintes manuelles en milieu de journée. Les surfaces associées aux méthodes allaient de 0,18 et $0,49 \mathrm{~m}^{2}$ respectivement, pour les enceintes manuelles et automatiques, à plus de $10^{4} \mathrm{~m}^{2}$ pour les mesures micrométéorologiques. Les profils de densité apparente, de teneurs en eau, températures et concentrations en $\mathrm{NO}_{3}-$ et $\mathrm{NH}_{4}{ }^{+}$ont été suivis simultanément aux mesures de flux de $\mathrm{N}_{2} \mathrm{O}$. Les différentes méthodes ont abouti à des estimations similaires. Le flux de $\mathrm{N}_{2} \mathrm{O}$ moyenné sur l'ensemble de la période commune de suivi étant de l'ordre de $6 \mathrm{ng} \mathrm{N}-\mathrm{N}_{2} \mathrm{O} \mathrm{m}^{-2} \mathrm{~s}^{-1}$. L'utilisation de 16 chambres manuelles a montré une grande variabilité spatiale des émissions comprise entre 30 et $150 \%$ pendant les deux semaines de mesure. Cette variabilité pourrait expliquer la forme inhabituelle des profils de concentrations atmosphériques observés par les méthodes des gradients. Les flux horaires donnés par les mesures micrométéorologiques présentaient une variabilité de l'ordre de $100 \%$ sur des périodes journalières : on peut penser à de faibles variations des processus microbiens à ces échelles de temps et attribuer cette variabilité à des phénomènes physiques comme les fluctuations de la pression de l'air. Les faibles émissions de $\mathrm{N}_{2} \mathrm{O}$ s'expliquent par de faibles précipitations avant et au cours de la période expérimentale, insuffisantes pour créer des conditions anoxiques dans le sol et pour qu'il puisse y avoir eu entrainement des fertilisants azotés vers les horizons plus humides. (@ Inra/Elsevier)

flux de protoxyde d'azote / effet de serre / dénitrification / sol / méthodes micrométéorologiques / méthodes par chambres au sol

\section{INTRODUCTION}

Soils have been identified by the Intergovernmental Panel on Climate Change (IPCC, 1995) as the major source of atmospheric nitrous oxide (Smith et al, 1994). Contributions from cultivated fields are estimated to be $3.5 \mathrm{Tg}$ year $^{-1}$, with a possible actual value between

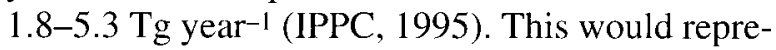
sent approximately two thirds of the probable 5.7 $\mathrm{Tg}$ year-1 anthropogenic sources of $\mathrm{N}_{2} \mathrm{O}(3.7-7.7$ $\mathrm{Tg}$ year-1) and therefore explain most of the observed annual increase in atmospheric $\mathrm{N}_{2} \mathrm{O}$. There is evidence that the flux of $\mathrm{N}_{2} \mathrm{O}$ from agricultural land (fertilized fields and grassland) is one of the major and increasing contributors to total global emissions of this gas: emissions increase with cultivation and increasing inputs of $\mathrm{N}$ in the form of mineral fertilizers or organic manure (Bouwman, 1990; Granli and Bockman, 1994). However, uncertainty persists as regards the fluxes attributable to cultivated soils (Smith, 1990), and improving assessment of $\mathrm{N}_{2} \mathrm{O}$ fluxes from fertilized land is a clear priority for research. Quantitative relationships between soil properties and other environmental factors are not yet sufficiently well understood to permit prediction of emissions over different time scales and extended regions and to assess the global $\mathrm{N}_{2} \mathrm{O}$ budget (Granli and Bockman, 1994; Mosier et al, 1996). A variety of techniques have been developed to measure surface-atmosphere gas exchange. Most estimations of $\mathrm{N}_{2} \mathrm{O}$ emission rates in the field have been based up to now on the use of various static chamber techniques (Hutchinson and Livingston,
1993; Hénault and Germon, 1995; Arah and Smith, 1990) and many studies have demonstrated a high degree of spatial and temporal variability in denitrification and $\mathrm{N}_{2} \mathrm{O}$ fluxes (Ambus and Christensen, 1994; Folorunso and Rolston, 1984; Parkin, 1987). In order to obtain reliable estimates of $\mathrm{N}_{2} \mathrm{O}$ fluxes at the field scale, numerous chambers are necessary. Recent technological advances have dramatically improved our ability to perform precise real-time measurement for minor compounds such as $\mathrm{N}_{2} \mathrm{O}$ by micrometeorological methods.

Each technique presents its advantages and drawbacks, and no single approach is applicable to all field conditions. Enclosure techniques are relatively low in cost, simple to operate, and especially useful for addressing research objectives based on discrete spatial observations. They are adaptable to a wide variety of field conditions from local to global spatial scales (Hénault et al, 1996; Clayton et al, 1994). Estimating emission at the field scale, however, requires many measurements so that the temporal and spatial variability of emission can be overcome. The chambers also physically disrupt the surface and atmosphere by altering the radiation environment, temperature, humidity and by cutting pressure fluctuations within the chambers (Livingston and Hutchinson, 1995). Such disruptions are likely to affect the rate of $\mathrm{N}_{2} \mathrm{O}$ emission.

An alternative non-disruptive approach is offered by micrometeorological techniques (Cellier, 1995), which integrate $\mathrm{N}_{2} \mathrm{O}$ emissions at the field scale (1-10 ha). These techniques involve the measurement of meteorological data and gas 
concentration at a location site above the soil-vegetation surface. The associated fluxes are representative of the upwind terrain. The conditions required by the method are a large fetch of uniform source surface $(100-500 \mathrm{~m})$, which in many applications may be a limitation.

An experiment was carried out to measure $\mathrm{N}_{2} \mathrm{O}$ fluxes at different scales, ranging from less than $0.5 \mathrm{~m}^{2}$ by traditional manual chamber methods or by automated chamber techniques and to more than 1 ha by micrometerological methods. In this paper the performances and the sensitivity limits of each technique were evaluated and the various $\mathrm{N}_{2} \mathrm{O}$ fluxes obtained with these different approaches were compared. The possible reasons for these differences were also explored.

\section{MATERIALS AND METHODS}

\section{Experimental site}

The experimental site was a flat cultivated field near Dijon (Burgundy, France), $47^{\circ} 12^{\prime}$ latitude north and $5^{\circ} 23^{\prime}$ longitude east. The experiment was performed from 23 October to 10 November 1995. The soil (Haplic Luvisol in the FAO classification) was a deep sandy loam brown soil of the Saône Terrace with a sand content of $47 \%$ and a clay content of $12.5 \%$. Its organic $\mathrm{C}$ content was $1.4 \%$ and its water $\mathrm{pH}$ was 6 . A bulk density profile was carried out with measurements taken every $0.05 \mathrm{~m}$ from the soil surface to $0.5 \mathrm{~m}$ in depth using a gamma-ray transmission probe from InraLCPC (Bertuzzi et al, 1987). The experimental field $(\sim 3 \mathrm{ha})$ was bordered by a path on one side and a grove on the other. Cultivated fields flanked the other sides. The field was cultivated with wheat in 1995 and ploughed after the harvest. Three days before the experiment began, $150 \mathrm{~kg} \mathrm{~N}$ ha-1 were applied as $\mathrm{NH}_{4} \mathrm{NO}_{3}$ and the field was then harrowed to a depth of $0.1 \mathrm{~m}$ to limit spatial heterogeneity due to $\mathrm{N}$ fertilization.

On 25 October 1995 all the equipment for flux measurement was installed. Location of the different equipment and sampling sites in the field are presented in figure 1 .

\section{$\mathrm{N}_{2} \mathrm{O}$ emission measurements by closed chamber methods}

Closed chambers of two designs were used. A set of 16 manual chambers (MA-CH) having a surface of $0.18 \mathrm{~m}^{2}$ was used as the first method. The chambers were composed of hollow PVC cylinders, 0.50 and $0.15 \mathrm{~m}$ in diameter and height, respectively. They were positioned in the soil for the whole experiment at a depth of approximately $0.08 \mathrm{~m}$ at the same location. The 16 chambers were arranged all over the field

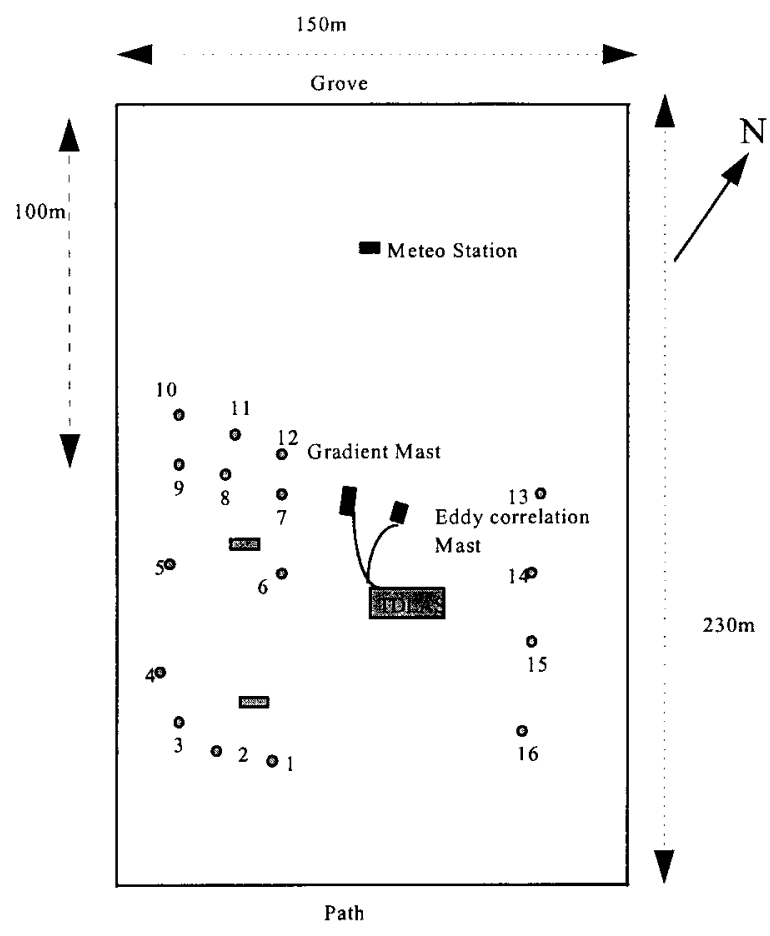

Fig 1. Location of equipment and sampling sites in the experimental field. ( ) manual chambers; automatic chambers; micrometeorological mast (eddy correlation and gradient).

according to figure 1. During the measurement of $\mathrm{N}_{2} \mathrm{O}$ fluxes, these chambers were sealed with a PVC lid fitted with a ring of foam rubber to ensure adhesion to the chambers. The lids were kept in place by a metal cross fixed to the chambers. Tiny holes in the lids maintained the internal pressure of each chamber to atmospheric pressure. $\mathrm{N}_{2} \mathrm{O}$ emissions were estimated over a 2 h 15 min period. The atmosphere in the chamber was sampled four times during this period using blood collecting tubes (Terrumo $3 \mathrm{~mL}$ ). These tubes were previously purged of components interfering with $\mathrm{N}_{2} \mathrm{O}$ analysis. $\mathrm{N}_{2} \mathrm{O}$ was thereafter analyzed by electron capture chromatography (sensitivity c. 20 ppbv) with Varian Star Workstation integrated software.

The second design consisted of two square automatic chambers (AU-CH) having a surface of $0.49 \mathrm{~m}^{2}$ and constructed from galvanized iron. Their characteristics were kindly supplied by K. Smith and A. Scott (University of Edinburgh and Scottish Agricultural Centre, UK, respectively). The chambers were 0.70 and $0.25 \mathrm{~m}$ in length and height, respectively, and sunk into the soil at approximately $0.1 \mathrm{~m}$ and positioned at around 30 and $100 \mathrm{~m}$ from the sonic mast south of the field (fig 1). Opening, closing and gas sampling were performed automatically. Each chamber was connected to a set of 24 loops in copper tubes $(40 \mathrm{~cm}$ in length, $1 / 8$ ', ie, $0.9 \mathrm{~mL}$ volume approximately) with two Teflon tubes. Commutation between these loops was achieved by two scanning-valves; air was circulated between the chambers and each loop was filled with an air-pump. Kinetics of $\mathrm{N}_{2} \mathrm{O}$ emissions were performed for two periods of $3 \mathrm{~h}$ every day, ie, between 1:00 and 
4:00 and between 13:00 and 16:00 UT. For each period, three gas samplings were taken. $\mathrm{N}_{2} \mathrm{O}$ concentrations were thereafter analyzed in laboratory by electron gas chromatography with HP 5890 Series II having two Porapak Q columns (10 and $6 \mathrm{ft}$ ) coupled to a Hewlett Packard Vectra Workstation integrated software. Its sensitivity was around $20 \mathrm{ppbv} \mathrm{N}_{2} \mathrm{O}$.

In both methods, $\mathrm{N}_{2} \mathrm{O}$ fluxes were estimated by the following equation:

$$
F=\alpha \frac{P}{R T} \overline{h_{\mathrm{c}}} M_{\mathrm{N}-\mathrm{N}_{2} \mathrm{O}}
$$

where $F$ is the $\mathrm{N}_{2} \mathrm{O}$ flux (ng N-N $\mathrm{O} \mathrm{m}^{-2} \mathrm{~s}^{-1}$ ), $\alpha$ is the rate of $\mathrm{N}_{2} \mathrm{O}$ accumulation of the chambers $\left(\mathrm{m}^{3} \mathrm{~m}^{-3} \mathrm{~s}^{-1}\right)$, $P$ the absolute pressure ( $\mathrm{Pa}), R$ the gas constant $(8.315$ $\mathrm{J}$ mol-1 $\left.\mathrm{K}^{-1}\right), T$ the absolute temperature $(\mathrm{K}), h_{\mathrm{c}}$ the mean height of the chamber above the soil surface $(\mathrm{m})$ and $M_{\mathrm{N}-\mathrm{N}_{2} \mathrm{O}}$ the molar weight of nitrogen of $\mathrm{N}-\mathrm{N}_{2} \mathrm{O}$ (ng). The values of $T$ and $P$ were taken to be equal to laboratory temperature and pressure during $\mathrm{N}_{2} \mathrm{O}$ gas analysis. The accumulation kinetics were considered to be significant when the correlation coefficient was higher than 0.9 ( $n=4$ : manual chamber, $n=3$ : automatic chamber, with $n$ the number of samples). If not, the estimated values were still used when the range of the gas mixing fraction during the kinetic was lower than $0.1 \mathrm{ppmv}$, corresponding approximately to a flux of $1.6 \mathrm{ng} \mathrm{N}-\mathrm{N}_{2} \mathrm{O} \mathrm{m}^{-2} \mathrm{~s}^{-1}$ for the automatic chambers. Otherwise, data were not considered as relevant because of the lack of linearity.

The relative flux error may be approximated by a first order limited development of equation [1]. The resulting expression is:

$$
\frac{\sigma_{F}}{F}=\sqrt{\left(\frac{\sigma_{\alpha}}{\alpha}\right)^{2}+\left(\frac{\sigma_{p}}{P}\right)^{2}+\left(\frac{\sigma_{T}}{T}\right)^{2}+\left(\frac{\sigma_{\overline{h_{c}}}}{\bar{h}_{c}}\right)^{2}}
$$

where $\sigma_{\alpha}, \sigma_{P}, \sigma_{T}$ and $\sigma_{\bar{h}}$ are the standard deviations of $\mathrm{N}_{2} \mathrm{O}$ accumulation rate, air pressure, temperature and mean chamber height, respectively. The relative uncertainty of each of these four terms was estimated: the uncertainties on $P, T$, and $\bar{h}_{\mathrm{c}}$ measurements led to a relative emission uncertainty of $\pm 2,3$ and $2 \%$, respectively. A sensitivity of $\pm 5 \%$ on detection of low accumulation rates $(\alpha)$ of $\mathrm{N}_{2} \mathrm{O}$ was reached according to the two GC characteristics. The mean error on flux measurements with chambers was then less than $\pm 7 \%$.

\section{$\mathrm{N}_{2} \mathrm{O}$ emission measurements by micrometeorological methods}

Micrometeorological fluxes were determined by two methods: 'gradient' and 'eddy correlation'. The gradient method was used for continuous monitoring of fluxes and the eddy correlation technique was used for $4 \mathrm{~d}$ and restricted to short periods (less than $5 \mathrm{~h}$ ). The $\mathrm{N}_{2} \mathrm{O}$ mixing ratio observations used for the micrometeorological method were made with a tunable diode laser absorption spectrometer (TDLAS) (Aerodyne
Research Inc, Billerica, MA, USA) system (Kolb et al, 1995).

\section{Gas analyser (TDLAS)}

The TDLAS uses a multipass absorption Herriott cell with an optical path length of $36 \mathrm{~m}$ and a small volume cell $(0.27 \mathrm{~L})$, operated at reduced pressure ( 35 Torr) to minimize interference from nearby spectral lines. Tuning of the laser emission wavelength to the selected absorption line $\left(2207.6 \mathrm{~cm}^{-1}\right)$ was accomplished by the appropriate setting of laser temperature (around $88 \mathrm{~K}$ ) and current through the diode, while small variations in the laser current (ramp) were used to scan absorption across the full infrared transition line shape. The spectral information was analyzed in real time. The diode laser power spectrum (baseline) was represented as a slowly varying polynomial of adjustable order; typically a quadratic or cubic polynomial was used. The area between the absorption line and the polynomial baseline, together with the absorption coefficient for the line and path length, was used to calculate the absolute concentration of $\mathrm{N}_{2} \mathrm{O}$.

To avoid the need for density corrections due to water vapour and heat fluctuations (Webb et al, 1980), the air was dried by a counterflow Perma Pure dryer and equilibrated to constant temperature before entering the optical cell. Under field conditions, the instrument precision (RMS) was $0.1 \%$ at $1 \mathrm{~Hz}$ and $1 \%$ at 10 $\mathrm{Hz}$. The major problem with this instrument during extended observation times was that a shift in the frequency emission was induced by laser diode temperature regulation drift. In this case the area defined by the baseline and the absorption line for a fixed concentration could be modified causing a drift in the evaluation of the $\mathrm{N}_{2} \mathrm{O}$ mixing ratio in the long term. For the eddy correlation measurements, this problem was solved by using a low-frequency filter in the data processing.

\section{Gradient measurements}

The micrometeorological theory for $\mathrm{N}_{2} \mathrm{O}$ flux measurement by the gradient method has been described in detail by Thom (1975) and Monteith and Unsworth (1990), and has been widely applied to trace gas fluxes. The following provides a brief overview of the method applied.

In the equilibrated constant-flux layer established over large uniform areas, the flux of any trace gas may be calculated as:

$$
F=-u^{*} \cdot c^{*}
$$

where $F$ is the flux of the trace constituent (ng $\mathrm{N}-\mathrm{N}_{2} \mathrm{O}$ $\left.\mathrm{m}^{-2} \mathrm{~s}^{-1}\right) . u^{*}$ and $c^{*}$ are horizontal velocity $\left(\mathrm{m} \mathrm{s}^{-1}\right)$ and $\mathrm{N}_{2} \mathrm{O}$ concentration (ppbv) scales defined by the wind, $u(z)$ or concentration $c(z)$ vertical profiles according to the equations:

$$
u(z)=\frac{u^{*}}{k}\left[\ln \left(\frac{z}{z \ddot{\mathrm{O}}}\right)-\Phi_{\mathrm{n}}\left(\frac{z}{L}\right)\right]
$$




$$
c(z)=\frac{c^{*}}{k}\left[\ln \left(\frac{z}{z \ddot{\mathrm{o}}}\right)-\Phi_{\mathrm{h}}\left(\frac{z}{L}\right)\right]
$$

The terms $\Phi_{\mathrm{m}}$ and $\Phi_{\mathrm{h}}$ are empirical non-dimensional stability correction functions for momentum and heat or gas concentration (Brutsaert, 1982); $z \ddot{o}$ is the roughness length, $k$ is von Karman constant $(k=0.41)$, and $L$ is the Monin-Obukhov length depending on the stability of the atmosphere. In the referentials defined by the bracket terms, the slope coefficients $u^{*}, c^{*}$ and errors on the slope $\left(\sigma_{u^{*}}\right.$ or $\left.\sigma_{c^{*}}\right)$ are obtained by a linear regression using equations [4] and [5].

By deriving the flux expression (equation [3]), flux error including instrumental and 'model' uncertainty will be estimated as follows:

$$
\frac{\sigma_{F}}{F}=\sqrt{\left(\left(\frac{\sigma_{c^{*}}}{c^{*}}\right)^{2}+\left(\frac{\sigma_{u^{*}}}{u^{*}}\right)^{2}\right)}
$$

The measurements were made at five heights $(0.1$, $0.3,0.7,1.1$ and $1.5 \mathrm{~m}$ ) above the soil surface. Wind speed was measured with opto-electronic cup anemometers (Cimel, Paris, France) with a stalling speed of about $0.3 \mathrm{~m} \mathrm{~s}^{-1}$ and air temperature with copper-constantan thermocouples (AWG24) placed in a double-shielded aspired screen. Five inlet tubes allowed the air sample to be directed into the cell of the TDL spectrometer over a distance of $20 \mathrm{~m}$. The switching between heights was performed by five two-way valves. A sequential cycle for $\mathrm{N}_{2} \mathrm{O}$ measurement was carried out to reduce the temporal variability between scans of each level. The five valves were switched alternatively every $36 \mathrm{~s}$, and the data were recorded after $10 \mathrm{~s}$ in order to allow residual air from the inlet tube cell to be removed. The average wind speed, temperature and $\mathrm{N}_{2} \mathrm{O}$ mixing ratio were recorded every 15 min on a CR10 datalogger (Campbell Scientific, Shepshed, UK) together with standard deviation on $\mathrm{N}_{2} \mathrm{O}$ mixing ratio.

To overcome the variability due to the measurement conditions by the gradient method the hourly mean fluxes, $F_{p}$ were calculated from 15 -min fluxes weighted by the inverse flux error ratio as follows:

$$
F_{p}=\sum_{i=1}^{4} P_{i} \cdot F_{i} \quad \text { with } \quad P_{i}=\frac{1}{\Delta F_{i} \sum_{j=1}^{4} \frac{1}{\Delta F_{j}}}
$$

$F_{i}$ and $\Delta F_{i}$ are the 15-min fluxes and flux errors deriving from equations [3] and [6], respectively. $P_{i}$ the weight assigned for each 15-min flux.

This treatment allowed the effect of 15 -min values with large uncertainties in the hourly flux to be minimized. The resultant hourly mean flux error was:

$$
\Delta F_{p}=\sqrt{\sum_{i=1}^{4} P_{i}^{2}\left(\Delta F_{i}\right)^{2}}
$$

\section{Eddy correlation measurements}

In this method the vertical flux density $F$ of a trace gas is written as the covariance between the vertical wind (w) and trace gas density (c) fluctuations as follows:

$$
F=\overline{w^{\prime} \cdot c^{\prime}}=\operatorname{cov}(w, c)
$$

where $w^{\prime}$ and $c^{\prime}$ are 15-min standard deviations from the mean vertical wind velocity and trace gas density, respectively.

The fluxes were calculated from $10-\mathrm{Hz}$ measurements integrated over 15 -min time intervals. A sonic anemometer (Gill Instruments, model 1012R2) mounted at a height of $1.0 \mathrm{~m}$ above the soil surface provided the three wind velocity components and air temperature. Concentrations of $\mathrm{N}_{2} \mathrm{O}$ were measured using the TDLAS. A Teflon tube, whose inlet point was located close to the sonic anemometer, allowed the air to be directed into the TDLAS cell. Since the TDLAS instrument was remote from the sampling mast, there was a time lag between wind and concentration measurements, depending on tube length, its section and the flow rate. The covariance between vertical wind and $\mathrm{N}_{2} \mathrm{O}$ concentration was calculated for different time shifts. The effective flux was obtained from the shift that gave the maximum covariance between vertical wind and $\mathrm{N}_{2} \mathrm{O}$ concentration. For synchronization, all the analog outputs of the TDLAS and the sonic anemometer were measured by a datalogger (21X, Campbell Inc, UK) at $10 \mathrm{~Hz}$. The data were continuously recorded by a micro-computer.

The error on the flux measurement by eddy correlation was also established as described for the gradient method, but on the basis of instrumental limitation only. Considering the flux expression it is possible to estimate the flux error according to the resolution of each sensor (see Appendix $A$ for details):

$$
\Delta F=\frac{1}{\sqrt{N}} \sqrt{\sigma_{w}{ }^{2} \cdot(\Delta c)^{2}+\sigma_{c}{ }^{2} \cdot(\Delta w)^{2}}
$$

where $N$ is the number of data used for the flux estimation and $\sigma_{w}{ }^{2}$ and $\sigma_{c}{ }^{2}$ are the vertical wind and $\mathrm{N}_{2} \mathrm{O}$ concentration variance, respectively. $\Delta w$ and $\Delta c$ are the resolution of the sonic anemometer and gas analyser, respectively.

In this method flux measurement errors may occur if the gas analysis system induces a cut-off frequency lower than the upper frequency corresponding to turbulence transport. Studies developed by Leuning (1996) and Lenschow (1991) indicated that air flow transport in pipes can cause concentration fluctuation attenuation. The normalized cut-off half-power frequency $\left(n_{0}\right)$ in pipes was described as a function of the Reynolds number, $\operatorname{Re}=2 a u_{t} / v$, with $a$ the tube radius $(\mathrm{m}), u_{t}$ the mean air flow velocity inside the tube $\left(\mathrm{m} \mathrm{s}^{-1}\right)$ and $v$ the kinematic viscosity of air $\left(\mathrm{m}^{2} \mathrm{~s}^{-1}\right)$. The Reynolds number must be compared to the normalized atmospheric turbulence flux frequency cut-off. Under neutral and unstable conditions, co-spectra for windspeed and temperature presented by Kaimal (1972) suggest that $95 \%$ of the flux in the surface layer occurs at frequencies below $f_{c} \sim 2 u_{a} /(z-d)$, where $u_{a}$ is the mean horizontal windspeed $\left(\mathrm{m} \mathrm{s}^{-1}\right), z$ the measurement height and $d$ the zero-plane deplacement $(\mathrm{m})$. In terms of 'pipe' flow 
normalized frequency the critical frequency $n_{c^{\prime}}$ may be then written as:

$$
n_{c}=\frac{(a x)^{1 / 2} f_{c}}{u_{i}}=\frac{4 a^{3 / 2} x^{1 / 2} u_{a}}{v \operatorname{Re}(z-d)}
$$

where $x$ is the distance along tube $(\mathrm{m})$. Damping of gas concentration will occur only if $n_{0}<n_{c}$ and will lead to flux underestimation. For the entire gas analysis line, three components could attenuate the $\mathrm{N}_{2} \mathrm{O}$ concentration signal: the sampling inlet tube, the Perma Pure dryer and the analysis cell.

Inside the sampling inlet tube $(20 \mathrm{~m}$ long and $4.2 \mathrm{~mm}$ inner diameter) the flow was turbulent with a Reynold number of 2800 and a flow velocity of $10 \mathrm{~m} \mathrm{~s}^{-1}$. In such conditions according to Lenschow (1991) the attenuation of concentration would be characterized by a normalized cut-off frequency of 0.11 $(\sim 5.3 \mathrm{~Hz})$; considering a value of $u_{d} /(z-d) \sim 1$ the normalized critical air turbulence flow frequency was equal to $0.04\left(f_{c} \sim 2 \mathrm{~Hz}\right)$.

The Perma Pure dryer consisted of $100,0.35$ long tube with small internal diameter tubes $(0.5 \mathrm{~mm})$. The flow inside these small tubes is laminar with a mean speed of $7 \mathrm{~m} \mathrm{~s}^{-1}$ and $\operatorname{Re} \sim 235$. This would lead to an attenuation of concentration with a normalized cut-off $n_{0}=0.06\left(f_{0} \sim 45 \mathrm{~Hz}\right)$ according to Lenschow (1991). The critical turbulence flow for this device is then $n_{c} \sim 0.003\left(f_{c}=2 \mathrm{~Hz}\right)$. For the Perma Pure dryer the condition $n_{0}>n_{c}$ was then widely satisfied.

For the TDLAS cell the time response depended on the air flow ' $V c$ ' through the analysis cell. The working pressure ( $\sim 40$ Torr) inside the cell and its device imposes a response time ' $t_{0}$ ' $\left(t_{0}=v_{t} / V_{c} \sim 0.08 \mathrm{~s}\right)$ to sweep one volume of air ' $v_{a}$ ' at a flow rate ' $V c$ ' through the chamber. The half-power frequency is then given by $f_{0}=3 / 2 \pi t_{0}=6 \mathrm{~Hz}$ and higher compare to the critical atmospheric turbulence frequency $\left(f_{c}=2 \mathrm{~Hz}\right)$

For this gas analysis system the main limiting factor for the turbulence signal bandwidth is the sampling inlet tube. Nevertheless, the Reynolds number inside was sufficient to maintain a high cut-off frequency and assumed no underestimate of the flux measurements.

\section{Additional measurements}

Measurements were taken in order to describe the variations in soil water content, temperature, nitrate $\left(\mathrm{NO}_{3}{ }^{-}\right)$ and ammonium $\left(\mathrm{NH}_{4}{ }^{+}\right)$concentrations. The average water content between the surface and a depth of $0.3 \mathrm{~m}$ was measured every hour with a time domain reflectometry probe (Trace, Soil Moisture, USA). Two parallel probes $0.45 \mathrm{~m}$ long were inserted in the soil at an inclination of $45^{\circ}$. Every 3 or $4 \mathrm{~d}$, measurements were made at depths of $0.02,0.05,0.1,0.15$ and $0.20 \mathrm{~m}$ with three parallel probes $0.2 \mathrm{~m}$ long, which were buried horizontally in the soil. The fraction of the pore space (WFPS) saturated with water was deduced from these measurements and the bulk density profiles made with a gamma ray probe (Linn and Doran, 1984).
Temperature was measured every hour at depths of $0.01,0.02,0.05,0.15,0.2,0.25,0.3$ and $0.5 \mathrm{~m}$ with chromel-alumel thermocouples.

In addition, the soil $\mathrm{NO}_{3}-$ and $\mathrm{NH}_{4}{ }^{+}$contents in the $0-0.2-\mathrm{m}$ horizon were periodically measured on six replicates randomly sampled over the whole field surface. The filtrate collected after soil ion extraction in the presence of $\mathrm{KCl} \mathrm{M}$ (soil solution ratio 1/5) was analysed by colorimetry with a continuous flux Technicon II analyser (Nicolardot, 1988).

\section{RESULTS AND DISCUSSION}

\section{Soil conditions}

The measurement of soil conditions during the experiment are presented in figure 2. During the experimental period, the soil water content was relatively low near the soil surface. The corresponding WFPS was above $60 \%$ only at depths equal to or higher than $0.15 \mathrm{~m}$ suggesting a low denitrification activity (Grundmann and Rolston, 1987) and that both denitrification and nitrification could be involved in $\mathrm{N}_{2} \mathrm{O}$ emission (Linn and Doran, 1984). The rainfall amounts were very low [ 10 mm, from day of the year (DOY) 298 to 308] and they only increased slightly the water content of the soil near the surface.

$\mathrm{NO}_{3}^{-}$and $\mathrm{NH}_{4}{ }^{+}$contents measured on the $0-20 \mathrm{~cm}$ varied from 10 to $70 \mathrm{mg} \mathrm{N} \mathrm{kg}^{-1}$ of soil during this experiment. Highest levels were observed for both $\mathrm{NO}_{3}-$ and $\mathrm{NH}_{4}{ }^{+}, 6 \mathrm{~d}$ after the $\mathrm{N}$ fertiliser application. Ten $\mathrm{d}$ after application the $\mathrm{N}-\mathrm{NO}_{3}{ }^{-}$and $\mathrm{N}-\mathrm{NH}_{4}{ }^{+}$levels were between 20 and $40 \mathrm{mg} \mathrm{N} \mathrm{kg-1}^{-1}$ soil.

Variation of $\mathrm{N}_{-} \mathrm{NO}_{3}{ }^{-}$and $\mathrm{N}-\mathrm{NH}_{4}+$ exhibited approximately about the same pattern and the same level. High spatial variabilities were observed for both $\mathrm{NO}_{3}-$ and $\mathrm{NH}_{4}{ }^{+}$with coefficient of variation (CV) ranged from 35 to $75 \%$. In addition, rainfall was not sufficient to permit the $\mathrm{N}$ fertilizer to move below $15 \mathrm{~cm}$.

Daily mean temperatures were steady on the seven first days of this experiment $\left(13^{\circ} \mathrm{C}\right)$. Then temperature decreased regularly during $4 \mathrm{~d}$ to a values near $5^{\circ} \mathrm{C}$.

\section{$\mathrm{N}_{2} \mathrm{O}$ emission estimates from the different methods}

Fluxes obtained during the experiment with the different methods are presented in figure 3 . The two automatic chambers were sampled twice a day 


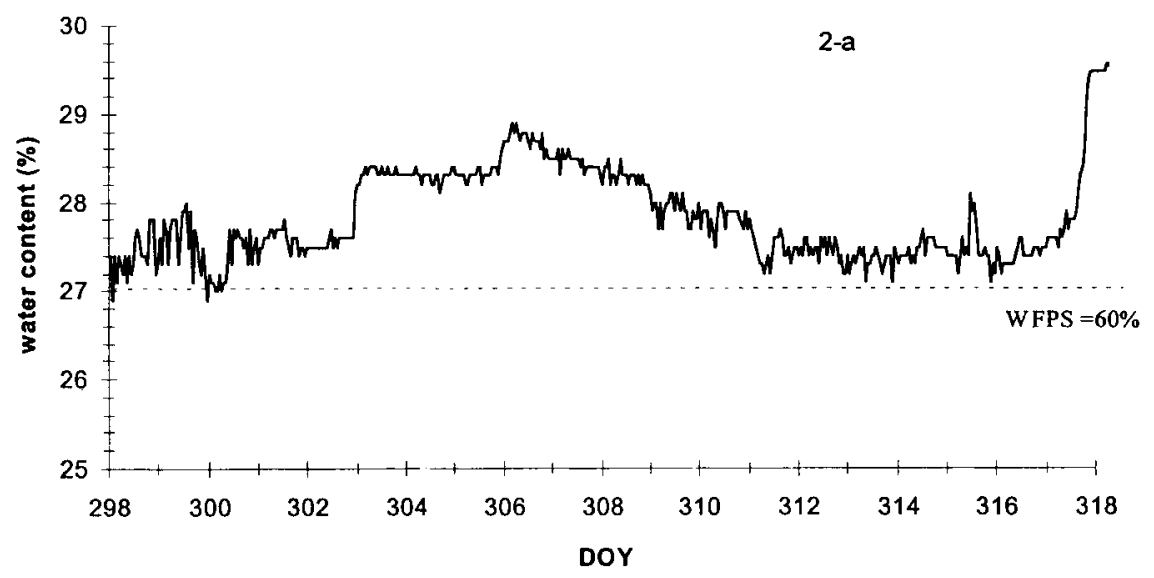

Fig 2. Soil conditions during the experiment. a. Integrated volumetric moisture content along the $0-0.3 \mathrm{~m}$ horizon. At $45 \%$ of water content the WFPS is equal to $100 \%$. b. Temperatures at depths of $0.1,0.2$ and $0.5 \mathrm{~m}$. c. Standard deviation and mean $\mathrm{NO}_{3}-$ and $\mathrm{NH}_{4}{ }^{+}$content integrated between soil surface and 0.2 m depth.

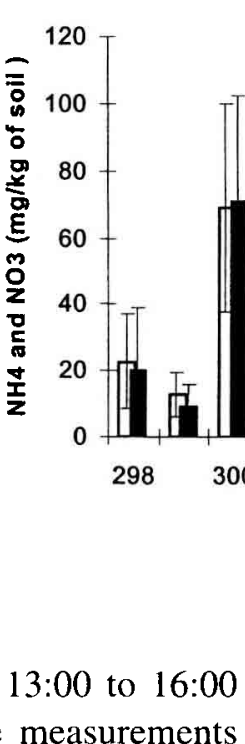

UT) from DOY 298 to 318 . The measurements obtained with both chambers were averaged (fig $3 a)$. Fluxes obtained with automatic chambers ranged from -0.5 to $13 \mathrm{ng} \mathrm{N}-\mathrm{N}_{2} \mathrm{O} \mathrm{m}^{-2} \mathrm{~s}^{-1}$. From DOY 298 to 308, fluxes were low with a mean midday value of $9 \mathrm{ng} \mathrm{N}-\mathrm{N}_{2} \mathrm{O} \mathrm{m}^{-2} \mathrm{~s}^{-1}$. After DOY 308 fluxes decreased with a mean midday value of $3 \mathrm{ng} \mathrm{N}-\mathrm{N}_{2} \mathrm{O} \mathrm{m}^{-2} \mathrm{~s}^{-1}$ and we observed a slight increase in $\mathrm{N}_{2} \mathrm{O}$ emission after DOY 315. Night- time fluxes were not always significant. This was notably the case for DOY 303, 304, 305 and 307.

The 16 manual chambers were sampled for $2 \mathrm{~h}$ 15 min near midday from DOY 298 to DOY 312. Figure $3 \mathrm{~b}$ shows the arithmetic means and standard deviations obtained from the 16 measurements. Mean fluxes obtained with the 16 chambers ranged from 0.7 to $12 \mathrm{ng} \mathrm{N}-\mathrm{N}_{2} \mathrm{O} \mathrm{m}^{-2} \mathrm{~s}^{-1}$. For individual chambers the fluxes ranged between 0.6 and $35 \mathrm{ng} \mathrm{N}-\mathrm{N}_{2} \mathrm{O} \mathrm{m}^{-2} \mathrm{~s}^{-1}$. $\mathrm{N}_{2} \mathrm{O}$ emissions between 

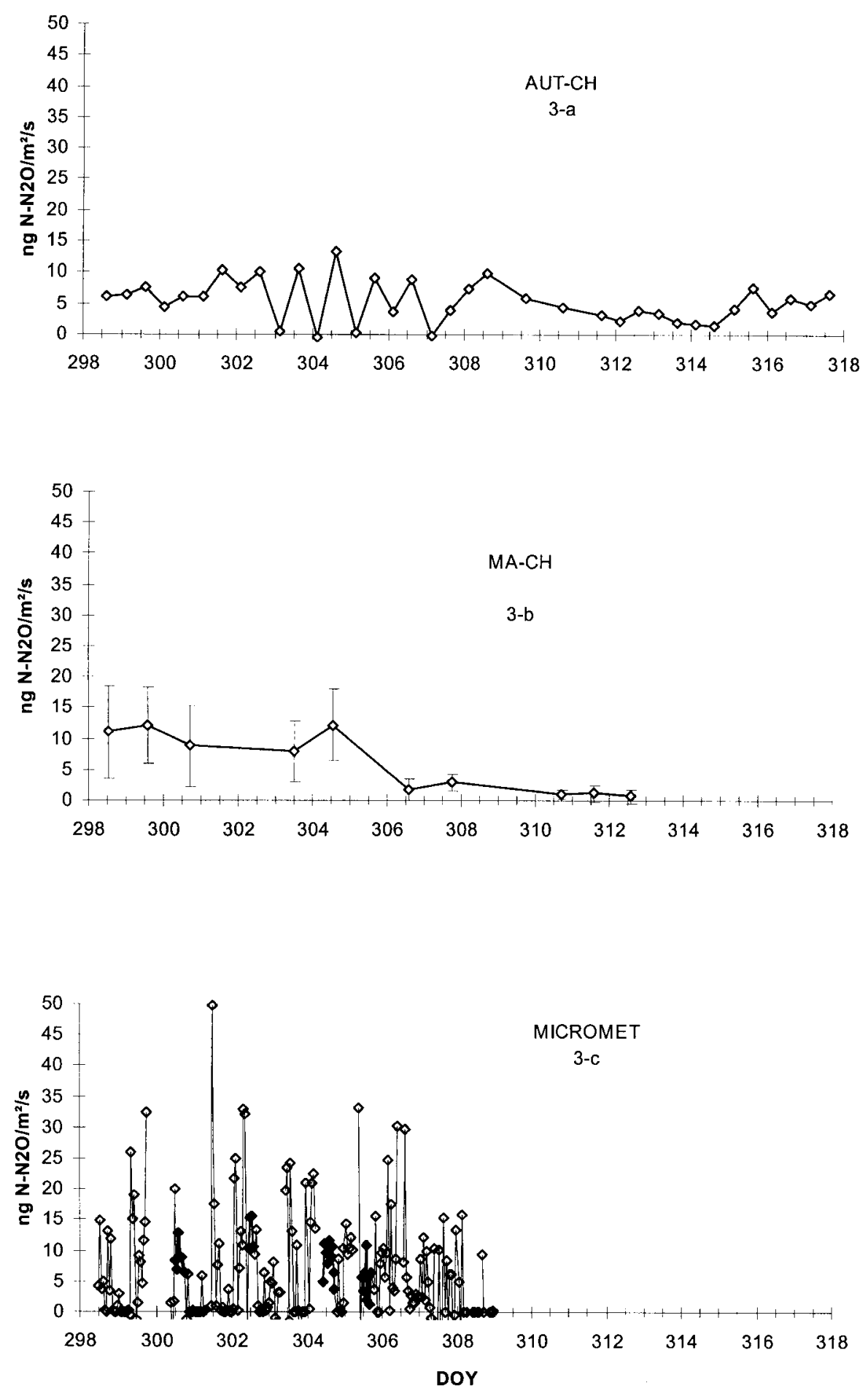

Fig 3. $\mathrm{N}_{2} \mathrm{O}$ fluxes obtained with different methods. a. With the automatic chamber (AUT-CH) sampled for $3 \mathrm{~h}$ at midnight and midday. b. With the 16 manual chambers (MA-CH) sampled for $2 \mathrm{~h} 15 \mathrm{~min}$ at midday. Error bars indicate the standard deviation obtained from the 16 measurements. c. With the hourly micrometeorological method: gradient (thin line) and eddy correlation (thick line).

DOY 298 and 305 had a mean midday value of 10 ng $\mathrm{N}-\mathrm{N}_{2} \mathrm{O} \mathrm{m}^{-2} \mathrm{~s}^{-1}$. After Julian day 305 a large decrease in emissions was observed with a mean value of $2 \mathrm{ng} \mathrm{N}-\mathrm{N}_{2} \mathrm{O} \mathrm{m}^{-2} \mathrm{~s}^{-1}$. The coefficients of variation (CV) ranged from 30 to $150 \%$ showing that spatial variability of $\mathrm{N}_{2} \mathrm{O}$ emissions was high. These values are in agreement with those published by Clayton (1994) and Ambus and
Christensen (1994). The highest CV values were observed in the case of lowest $\mathrm{N}_{2} \mathrm{O}$ fluxes when non-detectable fluxes were observed on chambers.

Hourly micrometeorological fluxes measured by eddy correlation and gradient methods are presented in figure 3c between DOY 298 and 308. Non-temporal discontinuities on the $\mathrm{N}_{2} \mathrm{O}$ flux levels have been observed between the data sets of 
the two methods. The micrometeorological fluxes were calculated every $15 \mathrm{~min}$ and averaged hourly. For the gradient method the hourly mean fluxes were calculated from 15-min fluxes weighted by the uncertainty according to equations [7] and [8].

For eddy correlation, the calculating flux error involves only the metrological uncertainties (which are themselves approximately equivalent). For this method a simple hourly mean was then used.

The hourly fluxes obtained from DOY 298 to 305 ranged from -5 to $50 \mathrm{ng} \mathrm{N}-\mathrm{N}_{2} \mathrm{O} \mathrm{m}^{-2} \mathrm{~s}^{-1}$, with a $6 \mathrm{ng} \mathrm{N}-\mathrm{N}_{2} \mathrm{O} \mathrm{m}^{-2} \mathrm{~s}^{-1}$ mean value. After DOY 307 , fluxes reduced with a mean daily value of $4 \mathrm{ng} \mathrm{N}$ $\mathrm{N}_{2} \mathrm{O} \mathrm{m}^{-2} \mathrm{~s}^{-1}$.

For all three methods, $\mathrm{N}_{2} \mathrm{O}$ fluxes were varied with soil temperature (fig $2 \mathrm{~b}$ ).

\section{Micrometeorological measurement sensitivity}

\section{Gradient method}

Figure 4a presents the variation in 15 -min averages of $\mathrm{N}_{2} \mathrm{O}$ concentrations during DOY 301 at heights of 0.1 and $1.5 \mathrm{~m}$ corresponding to the highest and lowest inlets for the gradient method. For this day the lowest height mean $\mathrm{N}_{2} \mathrm{O}$ concentration was $299 \mathrm{ppbv}$ with a mean standard deviation (obtained with five cycles of $26 \mathrm{~s}$, ie, 130 measurements) of $2.6 \mathrm{ppbv}(\sigma / \mathrm{m}=0.88 \%)$. For the upper inlet, the mean daily concentration was $296 \mathrm{ppbv}$ with an average mean standard deviation of $2.3 \mathrm{ppbv}(\sigma / \mathrm{m}=0.76 \%)$.

As expected, the relative mean standard deviation was higher near the soil surface, which indicated the proximity of $\mathrm{N}_{2} \mathrm{O}$ sources and a higher sensitivity to the $\mathrm{N}_{2} \mathrm{O}$ source distribution. In fact, each standard deviation would result from instrumental sensitivity $(0.3 \mathrm{ppbv}, 0.1 \%)$ and drift, but also and mainly from the temporal and spatial concentration fluctuations over the field.

The mean daily gradient between 0.1 and $1.5 \mathrm{~m}$ was $3 \mathrm{ppbv}$ and varied from $-0.5 \mathrm{ppbv}$ at midday to $10 \mathrm{ppbv}$ at night. The daily average standard deviation, calculated as the square root of the sum of the squares of the standard deviations of concentration differences, was 3.5 ppbv. Nevertheless, the mean gradient was usually measured more accurately, because mean standard gradient deviation accounted not only for instrumental resolution, but also for the change with time of emissions.
The flux uncertainty for DOY 301 was estimated from equation [6] (fig 4b). The average relative error $\left(\sigma_{F} / F\right)$ was about $50 \%$ over this day and varied between 5 and $350 \%$. To discriminate between the contribution of each component, we estimated the relative error linked to the $\mathrm{N}_{2} \mathrm{O}$ profile concentration $\left(\sigma_{c^{*}} / c^{*}\right)$ and wind speed profile $\left(\sigma_{u^{*}} / u^{*}\right)$. These values are presented in figure 4c. The average contributions of the two sources of error calculated over $24 \mathrm{~h}$ were similar, with a mean value of $33 \%$ for the $\mathrm{N}_{2} \mathrm{O}$ profile and $37 \%$ for the wind speed profile. The error linked to the wind gradient was larger at night because of low wind speed and associated strong stability. Conversely, the error linked to the concentration gradient was larger during the daytime with strong atmospheric unstability. With the gradient methods, the uncertainty with the measured flux depended on the differences of concentration between the highest and the lowest sampling points. The greater the difference in measurement height, the greater this concentration difference was likely to be. In practice, height was limited to $1 \%$ of the fetch, ie, $1.5 \mathrm{~m}$ under our conditions. The gradient magnitude also varied with wind speed; the higher the wind speed, the smaller the concentration gradient. At night, when the wind speed was low, the concentration gradient could be large due to low turbulent diffusion. In the daytime, the $\mathrm{N}_{2} \mathrm{O}$ gradient was low due to high wind speed and strong unstability and the uncertainty on the $\mathrm{N}_{2} \mathrm{O}$ profile was very high. The uncertainty might also have been caused by the spatial heterogeneity of the source. According to the variations in wind direction and velocity variation during the 15-min. sampling, the wind might have sampled zones with different source strength which introduced uncertainties into the gradient. Indeed, the gradient method approach requires that the source strength of $\mathrm{N}_{2} \mathrm{O}$ is to be spatially uniform to avoid the development of significant local advection contributions due to horizontal $\mathrm{N}_{2} \mathrm{O}$ flux gradients. The uncertainty in the log linear height versus $\mathrm{N}_{2} \mathrm{O}$ concentration observed during the experiment might be considered to be the consequence of a 'non-ideal' emission site.

\section{Eddy correlation method}

The error on fluxes with the eddy correlation method was studied by using the basis of equation [10]. The Gill sonic anemometer resolution was $\Delta w \sim 0.03 \mathrm{~ms}^{-1}$ and the TDLAS resolution was $\Delta c \sim 1.2 \mathrm{ppbv}$. Given the values of $\mathrm{N}_{2} \mathrm{O}$ concentration and vertical wind variance $\left(\sigma_{c}{ }^{2}, \sigma_{w}{ }^{2}\right)$ during the experiment, the errors for a 15 -min time inter- 

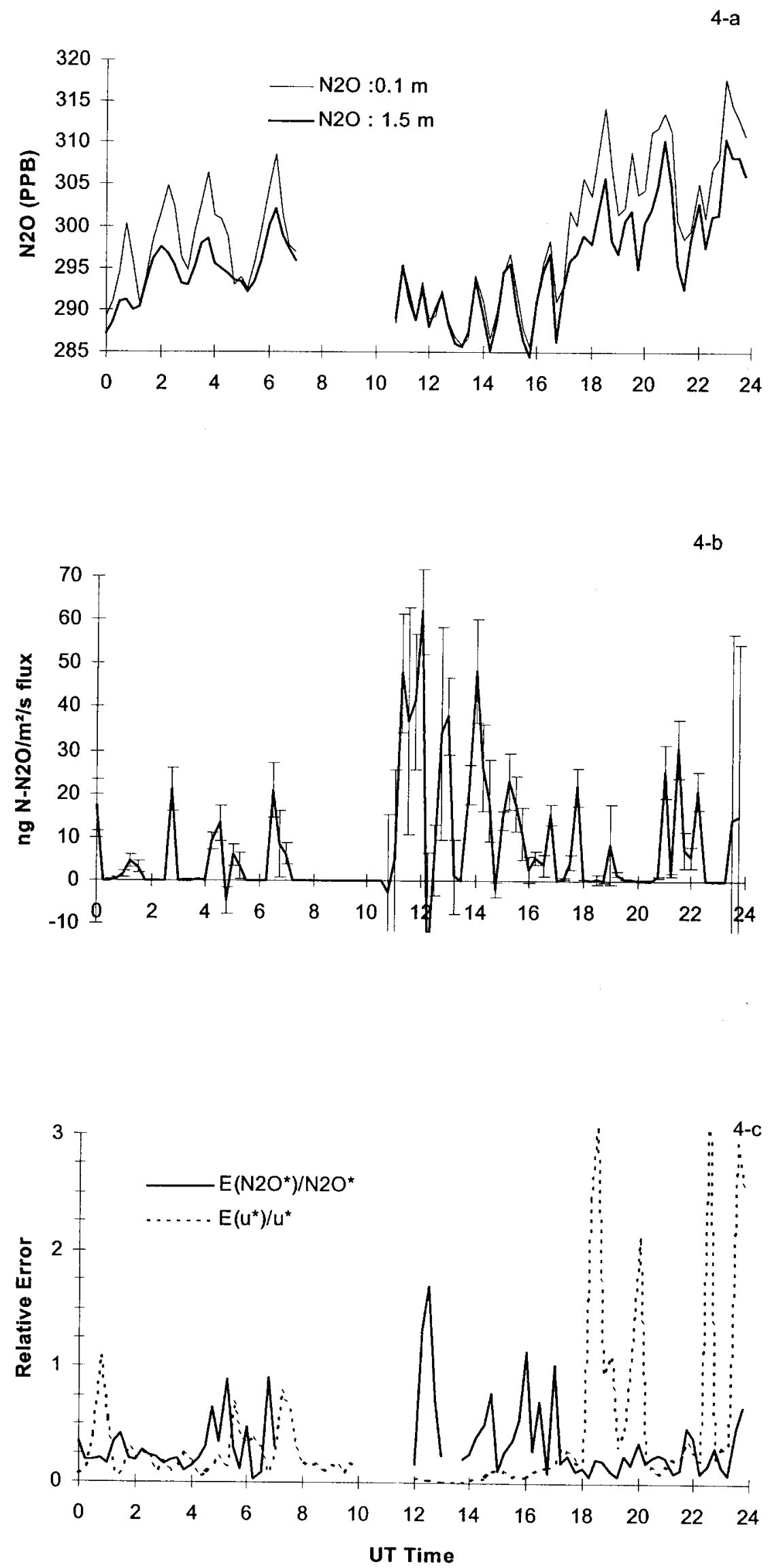

Fig 4. Example of gradient measurements during DOY 301. a. Atmospheric concentration gradient between 1.5 and $0.1 \mathrm{~m}$ above the soil surface. b. 15-min fluxes and error bars obtained with the gradient method. c. Relative contribution of error linked to $\mathrm{N}_{2} \mathrm{O}$ concentration and wind vertical profiles. 
val ranged from 1 to $9 \mathrm{ng} \mathrm{N-N_{2 }} \mathrm{O} \mathrm{m}^{-2} \mathrm{~s}^{-1}$ with a mean value of $4 \mathrm{ng} \mathrm{N}-\mathrm{N}_{2} \mathrm{O} \mathrm{m}^{-2} \mathrm{~s}^{-1}$ and a mean relative error of $55 \%$. Considering the low $\mathrm{N}_{2} \mathrm{O}$ emission rate, measurements were affected by instrumental TDLAS drift and it was essential to remove low frequency noise from the $\mathrm{N}_{2} \mathrm{O}$ data.

\section{Intercomparison of flux measurement: effect of temporal and spatial variability}

\section{Temporal variability}

To show the variations in diurnal $\mathrm{N}_{2} \mathrm{O}$ emissions, the hourly mean fluxes obtained with micrometeorological measurements over ten successive days are presented in figure $5 \mathrm{a}$. In order to account for the $\mathrm{N}_{2} \mathrm{O}$ emission variation over the $10 \mathrm{~d}$, each hourly measurement was normalized by the mean daily flux. Also, to obtain mean hourly fluxes symmetrical around the time axis each flux was centered by their daily mean. Each relative flux $\left(F_{i, j}{ }^{\prime}\right)$ may be then written as follows:

$$
F_{i, j}{ }^{\prime}=\frac{F_{i, j}-m_{j}}{m_{j}}
$$

where $F_{i, j}$ is the hourly flux from the $i$ th hour of the day and $m_{j}$ is the mean flux from the $j$ th day of the $10-\mathrm{d}$ period.

In figure $5 \mathrm{a}$ the relative hourly means obtained from the $10 \mathrm{~d}\left(\overline{F_{i}^{\prime}}=\sum_{j=1}^{10} F_{i, j}^{\prime}\right)$ are shown. The error bars indicate the standard deviation observed over the 10 days. Except for 3:00 UT when standard deviation was particularly high, a diurnal tendency was observed with maximum $\mathrm{N}_{2} \mathrm{O}$ emissions between 9:00 and 16:00 UT.

In order to examine the possibility of using flux measurements from chambers as a mean daily flux estimate, chamber measurements were compared with the mean daily flux obtained with the micrometeorological methods (fig 5b). For the automatic chambers, the fluxes were averaged for
Fig 5. Temporal flux variabilities. a. Relative diurnal $\mathrm{N}_{2} \mathrm{O}$ fluxes observed by micrometeorological methods (see text for definition of Y-axis data). b. Mean daily flux estimates: from 2 h 15 -min integration time, corresponding to the 16 manual chambers (grey), from 6-h integration time, corresponding to the two automatic chambers (black) and from 24-h integration time, corresponding to micrometeorological fluxes (white). For these later error bars indicate the standard deviation obtained from 24 hourly measurements.
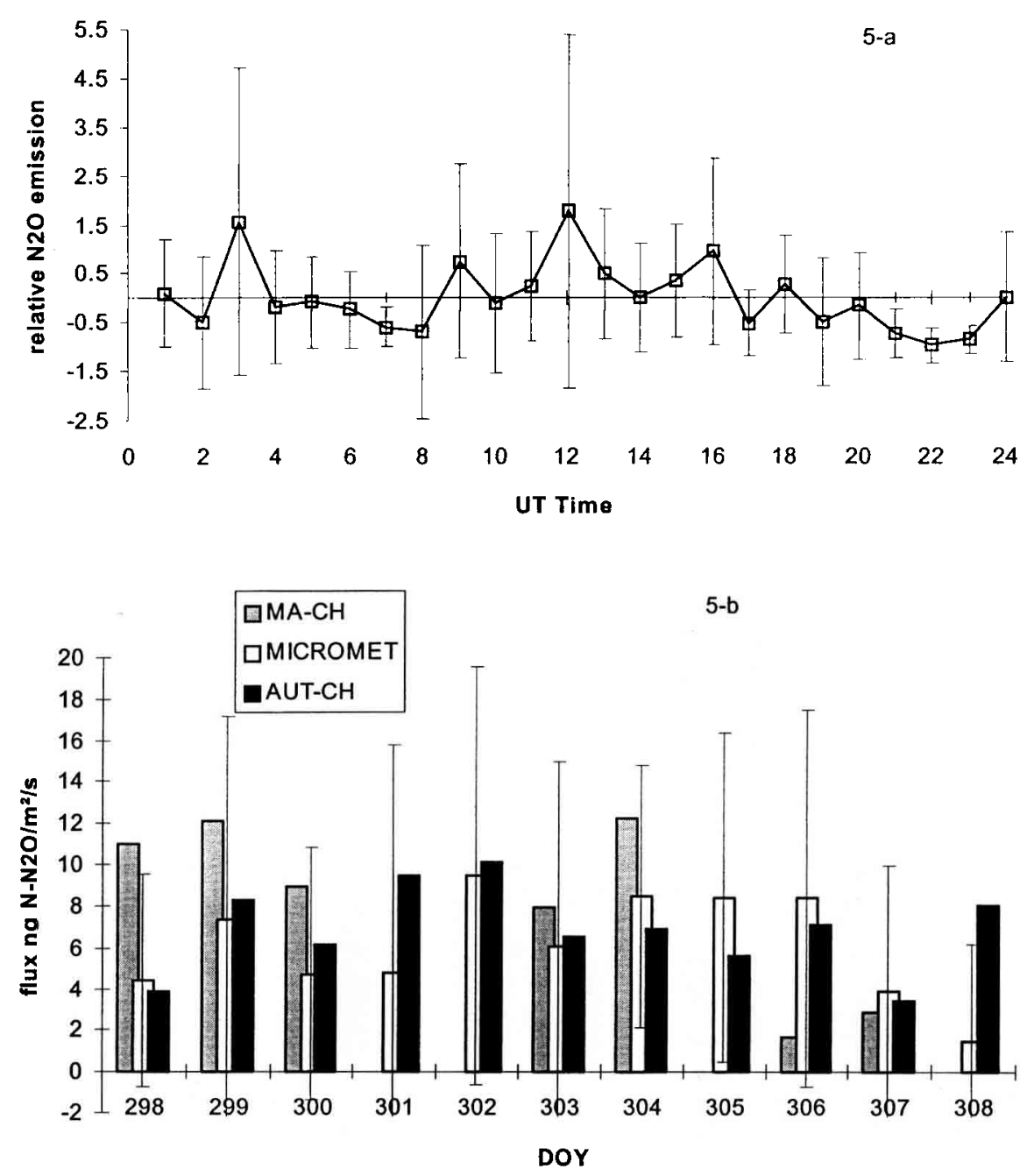
night and day. In figure $5 \mathrm{~b}$, the error bars on the micrometeorological data are the standard deviations for the 24 hourly fluxes of the corresponding day. Their amplitudes have the same order of magnitude as their mean values. Chamber measurements are within the error bars of micrometeorological fluxes. As could be expected, the mean values obtained with the automatic chambers and for the 6-h integration time were more representative of the daily mean emission obtained by the micrometeorological technique compared to the $2 \mathrm{~h} \mathrm{15-min} \mathrm{integration} \mathrm{time} \mathrm{measurements} \mathrm{of} \mathrm{the}$ manual chambers. Fluxes obtained with manual chambers with only 2 h 15 -min integration time during midday (except for day 306) are generally greater than the fluxes obtained with other techniques. This result may be expected with respect to the diurnal $\mathrm{N}_{2} \mathrm{O}$ emission variabilities (fig 5a). Therefore, it is important to monitor the emissions at different times in the day. Nevertheless, such a comparison would be more significant with a larger magnitude of emissions.

\section{Spatial variability}

The manual chambers at 16 different locations on the field were classified according to their respective flux magnitude. Each value of flux $F_{i, j}$ flux from the $i$ th chamber was 'centered' and 'normalized' by the mean daily flux $m_{j}$ obtained from the 16 chambers according to equation [12]. Figure $6 \mathrm{a}$ shows the mean and the standard deviation of those relative emissions, obtained from $10 \mathrm{~d}$ of measurements. For each chamber a rank was established, error bars are the standard deviations of the $10 \mathrm{~d}$ of measurement. This figure suggests that spatial variability is structured with emissions from some chambers always larger than over others. This is particularly the case with chamber 14 characterized by large emissions, which suggests a particular set of soil conditions favourable to $\mathrm{N}_{2} \mathrm{O}$ production; conversely chamber 4 was characterized by persistent low emissions (small error bars).

Figure $6 \mathrm{~b}$ shows the $\mathrm{N}_{2} \mathrm{O}$ fluxes measured by the various methods over the same time intervals
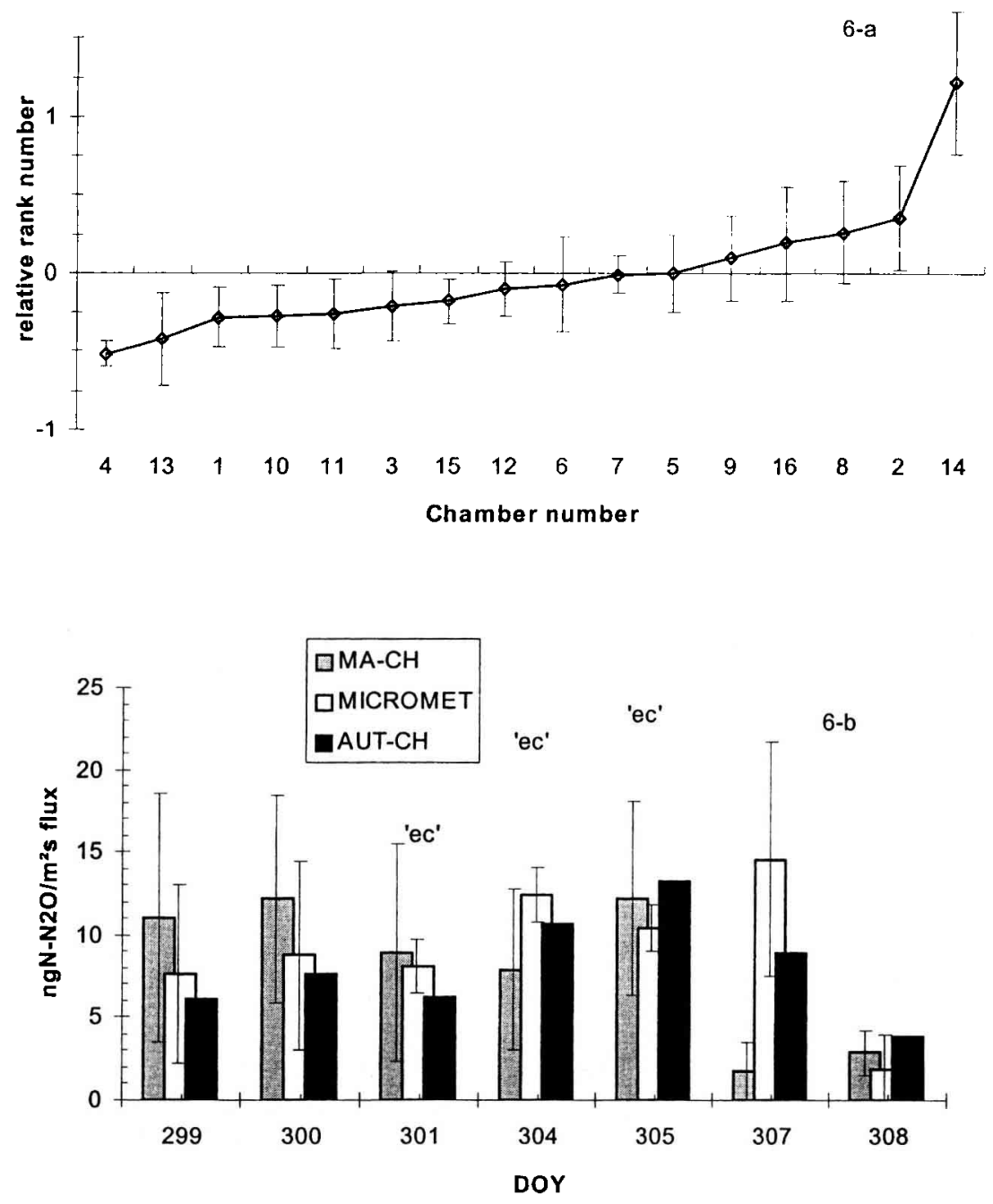

Fig 6. Spatial flux variability. a. Relative $\mathrm{N}_{2} \mathrm{O}$ emission rank of 16 manual chambers. Error bars indicate the dispersion around this relative rank for $10 \mathrm{~d}$ of measurement (see text for definition of $\mathrm{Y}$ axis data). b. $\mathrm{N}_{2} \mathrm{O}$ fluxes measured over the same time interval with the 16 manual chambers (grey) with the two automatic chambers (black) and with the micrometorological methods (white). For manual chamber fluxes error bars indicate standard deviations from the 16 chamber data. For micrometeorological fluxes the error bars indicate methodological uncertainties, corresponding for the 'eddy correlation' method (labelled 'ec') only to instrumental sensitivity, and for the 'gradient' method also to spatial variability of $\mathrm{N}_{2} \mathrm{O}$ emissions. 
over the ten consecutive days 298-307. Micrometeorological data were averaged over the time intervals when the chambers were covered. The fluxes obtained with the various methods at this temporal scale were closer than for the comparison at daily scale (fig $5 \mathrm{~b}$ ). Fluxes measured by the eddy correlation method are labelled 'ec'. The spatial variability of the manual chambers was quantified by the standard deviations obtained with the 16 enclosures. This variability is high when compared to the methodological uncertainty $(\leq 7 \%)$. Depending on the day, $\mathrm{CV}$ ranged between 45 and $150 \%$. For the micrometerological gradient method, the mean errors bars obtained theoretically with equation [6] over a 1-h integrating time according to equation [8] were in a similar range: $30-106 \%$. As explained previously, the error in the gradient method results from the instrumental resolution limits but also for a large part from non-ideal emission conditions with spatially heterogeneous sources. Error bars obtained by the eddy correlation method (equation [10]) are smaller and vary from 13 to $26 \%$ for 1-h integration times. They include only instrumental accuracy. The spatial variability of the soil $\mathrm{NO}_{3}{ }^{-}$and $\mathrm{NH}_{4}{ }^{+}$contents obtained with the six samples was of the same order of magnitude as that for $\mathrm{N}_{2} \mathrm{O}$ emission (fig 2c) suggesting that the heterogeneity in substrates distribution could have induced the existence of hot spots demonstrated by the ranking of chamber sites (fig 6a).

\section{CONCLUSION}

The objective of this study was to compare measurements of $\mathrm{N}_{2} \mathrm{O}$ fluxes under field conditions, which required integrating fluxes representative of different spatial and time scales. Measurements of $\mathrm{N}_{2} \mathrm{O}$ fluxes from an agricultural soil were obtained by different methods at a common site. Three methods, which measured fluxes over different areas $\left(0.18 \mathrm{~m}^{2}-10^{5} \mathrm{~m}^{2}\right)$, were used to quantify emission fluxes, and to access their spatial and temporal representativity.

Fluxes measured using two automated chambers, varied from -0.7 to $14 \mathrm{ng} \mathrm{N}-\mathrm{N}_{2} \mathrm{O} \mathrm{m}^{-2} \mathrm{~s}^{-1}$ during the campaign.

Fluxes measured with 16 manual chambers, varied from 0.6 to $35 \mathrm{ng} \mathrm{N}-\mathrm{N}_{2} \mathrm{O} \mathrm{m}^{-2} \mathrm{~s}^{-1}$, with a coefficient of variation of $\sim 65 \%$ and indicated large-scale (10-100 m) heterogeneity.

Hourly fluxes measured by micrometeorological methods, varied from -5 to $50 \mathrm{ng} \mathrm{N}-\mathrm{N}_{2} \mathrm{O} \mathrm{m}{ }^{-2}$ $\mathrm{s}^{-1}$ with a relative uncertainty of $\sim 40 \%$ for the gradient method. These measurements indicated large variations with time during the day with a CV of near $100 \%$ correlated with soil temperatures. This study confirmed that the micrometeorological techniques could be employed even for weak $\mathrm{N}_{2} \mathrm{O}$ emissions. The magnitude of the uncertainty of $\mathrm{N}_{2} \mathrm{O}$ fluxes was fairly large, because $\mathrm{N}_{2} \mathrm{O}$ sources were heterogeneous and measurements of small differences were made in a background concentration. Nevertheless, greater relative accuracy may be expected with larger emissions.

Despite weak $\mathrm{N}_{2} \mathrm{O}$ emissions (around $6 \mathrm{ng} \mathrm{N}$ $\mathrm{N}_{2} \mathrm{O} \mathrm{m}^{-2} \mathrm{~s}^{-1}$ on average), the correspondance between the different techniques was satisfactory. This study showed the temporal and the spatial variabilities in $\mathrm{N}_{2} \mathrm{O}$ emissions and showed the necessity of characterizing soil heterogeneity properties in terms of soil water content (which controls the degree of anoxia) and the nitrogen availability to help interprete the $\mathrm{N}_{2} \mathrm{O}$ flux variations. These results should be confirmed by measurements using a wide range of emission conditions.

Acknowledgements: This work was supported by the French programme Agriges of the ministère de l'Environnement, the Institut national de la recherche agronomique (Inra) and the Agence de l'environnement et de la maîtrise de l'énergie (Ademe). Jean-Claude Gaudu, Michel Bourlet, Sandrine Page, Sylvie Masson and Brigitte Durand (Inra) helped us for in-situ measurements. Inra Avignon laboratory is indebted to Keith Smith (University of Edinburgh) and Albert Scott (Scottish Agricultural Centre of Edinburgh), for providing them with the information required for the construction of the automatic chambers used in this study. We are grateful to Kathi Archbold-Zenon of the Translation Department of Inra for reviewing the English version of the manuscript.

\section{REFERENCES}

Ambus P, Christensen S (1994) Measurement of $\mathrm{N}_{2} \mathrm{O}$ emission from a fertilized grassland: an analysis of spatial variability. J Geophys Res 99, 549-555

Arah JRM, Smith KA (1990) Factors influencing the fraction of the gaseous product of soil denitrification evolved to the atmosphere as nitrous oxide. In: Soils and the Greenhouse Effect (AF Bouwman, ed), John Wiley and Sons, Chichester, UK, 475-480

Bertuzzi, P, Bruckler L, Gabilly Y, Gaudu GC (1987) Calibration, field testing, and error analysis of gamma-ray probe in situ measurement of dry bulk density. Soil Sci 144, 425-436

Bouwman AF (1990) Exchange of greenhouse gases between terrestrial ecosystems and the atmosphere. In: Soils and the Greenhouse Effect (AF Bouwman, ed), John Wiley and Sons, Chichester, UK, 61-127 
Brutsaert W (1982) Evaporation into the Atmosphere. D Reidel Publishing Compagny, London

Cellier P (1995) Méthodes de mesure des flux de gaztrace. Les dossiers de l'environnement de l'Inra 10, 23-27

Clayton H, Arah, JRM, Smith KA (1994) Measurement of nitrous oxide emissions from fertilized grassland using closed chambers. J Geophys Res 99, 599-607

Folorunso OA, Rolston DE (1984) Spatial variability of field-measured denitrification gas fluxes. Soil Sci Soc Am J 48,1214-1219

Granli T, Bockman OC (1994) Nitrous oxide from agriculture. Norv J Agri Sci (suppl) 12, 1-125

Hénault C, Germon JC (1995) Quantification de la dénitrification et des émissions de protoxyde d'azote $\left(\mathrm{N}_{2} \mathrm{O}\right)$ par les sols. agronomie 15, 321-355

Hénault C, Devis X, Delorme S, Devroe C, Reau R, Germon JC (1996) Nitrous oxide emissions in different agricultural and pedological situations. Transactions of the Nitrogen Workshop, Oral presentation, Braunschweig, September 1996, 145-148

Hutchinson GL, Livingston G.P (1993). Use of chamber systems to measure trace gas fluxes. In: Agricultural Ecosystem Effects on Trace Gases and Global Climate Change (LA Harper, AR Mosier, JM Duxburry, DE Rolston, eds), Am Soc Agron, Inc, Madison, WI, USA, 63-78

IPCC (1995) Climate Change 1994, Radiative Forcing of Climate Change and an Evaluation of the IPECAC IS92 Emission Scenario (JT Houghton, LG Meira Filho, J Bruce, L Hoesung, BA Callander, E Haites, N Harris, K Maskell, eds), Cambridge University Press, UK

Kaimal JC, Wyngaard JC, Izumi Y, Cote OR (1972) Spectral characteristics of surface layer turbulence. Quart J R Meteorol Soc 98, 563-589

Kolb CE, Wormhoudt JC, Zahniser MS (1995) Recent advances in spectroscopic instrumentation for measuring gases in the natural environment. In: Biogenic Trace Gases: Measuring Emission from Soil and Water (PA Matso, RC Harriss, eds), Blackwell Science, 259-290

Lenschow DH, Raupach MR (1991) The attenuation of fluctuations in scalar concentrations through sampling tubes. J Geophys Res 15, 15259-15268

Leuning R, Murray J (1996) The relative merits of open- and closed-path analysers for measurement of eddy fluxes. Global Change Biology 2, 241-253

Linn D M, Doran J M (1984) Effect of water-filled pore space on carbon dioxide and nitrous oxide production in tilled and non-tilled soils. Soil Sci Biochem $22,1267-1272$

Livingston GP, Hutchinson GL (1995) Enclosurebased measurement of trace gas exchange: applications and sources of error. In: Biogenic Trace Gases: Measuring Emission from Soil and Water (PA Matson, RC Harriss, eds), Blackwell Science, 14-51
Monteith, JL, Unsworth MH (1990) Principles of Environment Physics. Arnold, London

Mosier AR, Duxbury JM, Freney JR, Heinemeyer O, Minami K (1996) Nitrous oxide emissions from agricultural fields: assessment, measurement and mitigation. Plant Soil 181, 95-108

Nicolardot B (1988) Évolution du niveau de biomasse microbienne du sol au cours d'une incubation de longue durée: relations avec la minéralisation du carbone de l'azote organique. Ecol Biol Sol 25, 287304

Parkin T B (1987) Soil microsites as a source of denitrification variability. Soil Sci Soc Am J 51, 11941199

Smith KA (1990) Greenhouse gas fluxes between land surface and the atmosphere. Prog Phys Geog 14, 349-372

Smith KA, Clayton H, Arah JRM, Christensen S, Ambus P, Fowler D, Hargreaves J, Skiba U, Harris GW, Wienhold FG, Klemedtsson L, Galle B (1994) Micrometeorological and chamber methods for measurement of nitrous oxide fluxes between soils and the atmosphere: overview and conclusions. $J$ Geophys Res 99, 541-548

Thom AS (1975) Momentum mass and heat exchange. In: Vegetation and the Atmosphere (J Monteith, ed), Academic Press, NewYork, 57-109

Webb E K, Pearman G I, Leuning R (1980) Correction of flux measurements for chemistry effects due to heat and water vapor transfer. $Q J$ Roy Meteorol Soc $106,85-100$

\section{APPENDIX A. UNCERTAINTY OF THE EDDY CORRELATION METHOD}

This assessment includes only instrumental limitation. Given the flux expression it is possible to estimate the flux error according to the resolution of each sensor. The error on the flux is expressed as:

$$
\mathrm{d} F^{2}=\frac{1}{N^{2}} \sum_{i=1}^{N}\left[\left(\frac{\partial F_{i}}{\partial c_{i}^{\prime}}\right)^{2}\left(\mathrm{~d} c_{i}^{\prime}\right)^{2}+\left(\frac{\partial F_{i}}{\partial w_{i}^{\prime}}\right)^{2}\left(\mathrm{~d} w_{i}^{\prime}\right)^{2}\right]
$$

with

$$
F=\frac{1}{N} \sum_{i=1}^{N} F_{i}=\frac{1}{N} \sum_{i=1}^{N} w_{i}^{\prime} \cdot c_{i}
$$

The following equality was obtained

$$
\frac{1}{N} \sum_{i=1}^{N}\left(\frac{\partial F_{i}}{\partial c i}\right)^{2}=\sigma_{w}^{2} \text { and } \frac{1}{N} \sum_{i=1}^{N}\left(\frac{\partial F_{i}}{\partial w i}\right)^{2}=\sigma_{c}^{2}
$$

and

$$
\Delta F=\frac{1}{\sqrt{N}} \sqrt{\sigma_{w}{ }^{2} \cdot(\Delta c)^{2}+\sigma_{c}{ }^{2} \cdot(\Delta w)^{2}}
$$

